ANL-5925

Chemistry - General AEC Research and Development Report

ARGONNE NATIONAL LABORATORY

P. O. Box 299

Lemont, Illinois

\title{
A REVIEW OF THE UNCLASSIFIED LITERATURE ON NICKEL FLUORIDE
}

\author{
by \\ Robert K. Steunenberg \\ CHEMICAL ENGINEERING DIVISION
}

October 1958

Operated by The University of Chicago

under

Contract $W-31-109-$ eng- 38 


\section{DISCLAIMER}

This report was prepared as an account of work sponsored by an agency of the United States Government. Neither the United States Government nor any agency Thereof, nor any of their employees, makes any warranty, express or implied, or assumes any legal liability or responsibility for the accuracy, completeness, or usefulness of any information, apparatus, product, or process disclosed, or represents that its use would not infringe privately owned rights. Reference herein to any specific commercial product, process, or service by trade name, trademark, manufacturer, or otherwise does not necessarily constitute or imply its endorsement, recommendation, or favoring by the United States Government or any agency thereof. The views and opinions of authors expressed herein do not necessarily state or reflect those of the United States Government or any agency thereof. 


\section{DISCLAIMER}

Portions of this document may be illegible in electronic image products. Images are produced from the best available original document. 


\section{TABLE OF CONTENTS}

$\underline{\text { Page }}$

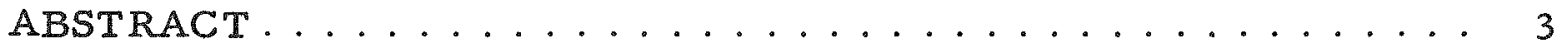

I. INTRODUCTION. . . . . . . . . . . . . . 3

II. PREPARATION OF NICKEL FLUORIDE. . . . . . . . . 3

III. THE POSSIBLE EXISTENCE OF HIGHER NIC KEL FLUORIDES . . . . . . . . . . . . . 6

IV. HANDLING OF ANHYDROUS NICKEL FLUORIDE $\ldots \ldots \ldots 7$

V. PHYSICAL PROPERTIES. . . . . . . . . . . . . 7

VI. CHEMICAL PROPERTIES - SOLUBILITIES AND

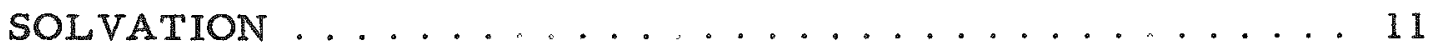

VII. CHEMICAL PROPERTIES - ADSORPTION OF GASES . . . . . 13

VIII. CHEMICAL PROPERTIES - REACTIONS OF NICKEL

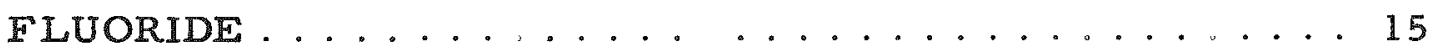

IX. CHEMICAL PROPERTIES - COMPLEX COMPOUNDS. . . . . 17

X. THERMOCHEMICAL DATA . . . . . . . . . . 22

BIBLIOGRAPHY. . . . . . . . . . . . . . . . 26 


\title{
A REVIEW OF THE UNCLASSIFIED LITERATURE ON NICKEL FLUORIDE
}

\author{
Robert K. Steunenberg
}

\begin{abstract}
A review of the unclassified literature on nickel fluoride is presented. Pertinent physical and chemical data are listed along with a bibliography containing 114 references.
\end{abstract}

\section{INTRODUCTION}

The properties of nickel fluoride are of special interest because of the extensive use of nickel and high-nickel alloys in equipment containing fluorine and highly reactive fluorides. The suitability of nickel for these applications is believed to depend upon the formation of a protective layer of nickel fluoride on the metal surface. Interest in nickel fluoride also arises from the fact that it frequently appears as an impurity in fluorides which have been handled in nickel equipment.

An attempt has been made to review the pertinent literature to date, to summarize important physical and chemical data, and to indicate where detailed information is available in the literature. It is hoped that this compilation of information on nickel fluoride will prove useful to those who have occasion to consult it.

\section{PREPARATION OF NICKEL FLUORIDE}

A. Reaction of Anhydrous $\mathrm{NiCl}_{2}$ with Fluorine $(76,78,114)$

Nickelous fluoride, $\mathrm{NiF}_{2}$, is the sole binary compound of nickel and fluorine. (76) It is the only nickel-containing product of the action of fluorine on anhydrous $\mathrm{NiCl}_{2}$, whereas the analogous reactions with the cobalt and iron salts yield the trifluorides.(76) Obviously this method was not used in much of the work listed in the bibliography, since fluorine itself was not isolated until 1886, and only relatively recently has it become a practical reagent. The method given by $H$. F. Priest (78) is probably the one most generally accepted at the present time:

A fluorine flow of $150 \mathrm{ml} / \mathrm{min}$ should be available. The fluorine should be passed through a dry-ice trap followed by a nickel absorption tube containing sodium fluoride pellets at $100 \mathrm{C}$. The preparative reaction is the following: 


$$
\mathrm{NiCl}_{2}+\mathrm{F}_{2} \longrightarrow \mathrm{NiF}_{2}+\mathrm{Cl}_{2}
$$

Fifty grams of hydrated nickel chloride are dried in a porcelain dish at $350 \mathrm{C}$ in a muffle furnace. Some hydrolysis occurs, but this is not serious, as nickel oxide does not interfere because it reacts fairly rapidly with fluorine. The dried nickel chloride is ground to pass a 30 -mesh screen and spread in the tray in as even a layer as possible.

The loaded tray is placed in a furnace tube and fluorine is passed over the nickel chloride while the furnace temperature is raised to $350 \mathrm{C}$. After three hours at this temperature, or when twice the calculated amount of fluorine has passed over the sample, the effluent gases are tested for chlorine by bubbling the gas through dilute alkali for one minute only, acidifying with nitric acid, and adding silver nitrate. The fluorine flow is continued for one hour after a negative chlorine test is obtained. The system is purged with nitrogen and the product is removed as a homogeneous, pale yellow powder. Although anhydrous nickel fluoride is non-hygroscopic unless mixed with hydrated nickel fluoride, the product should be kept in a desiccator.

B. Reaction of Anhydrous $\mathrm{NiCl}_{2}$ with Chlorine Trifluoride(87)

Chlorine trifluoride can be used in lieu of fluorine for the preparative reaction. Other halogen fluorides should be equally effective, although their use has not been reported. The chlorine trifluoride preparation is as follows:(87)

Fifty grams of nickel chloride hydrate are dried in a porcelain dish at $250 \mathrm{C}$; then the anhydrous chloride is ground to pass a 30-mesh screen. The powder is spread on a Monel tray within a reaction tube. Nitrogen is passed through the system as the tube furnace is heated to $250 \mathrm{~F}$. Chlorine trifluoride is passed until the reaction is complete; then the system is purged with dry nitrogen.

\section{Reaction of Anhydrous $\mathrm{NiCl}_{2}$ with Ammonium Fluoride}

Poulenc(18-20,22,24) and Ruff and Ascher(50) prepared crystalline nickel fluoride by melting excess ammonium fluoride together with anhydrous nickel chloride. The cooled mass was then extracted with boiling alcohol to remove the ammonium chloride. The yellow ammonium nickelous fluoride was heated to redness in inert gas. The nickel fluoride powder, when heated to $1200-1300 \mathrm{C}$ in dry hydrogen fluoride, became crystalline. 
D. Precipitation from Aqueous Solution by Hydrofluoric Acid

A nickel salt, such as the hydroxide, (33) nitrate(108) or carbonate, forms $\mathrm{NiF}_{2} \cdot 4 \mathrm{H}_{2} \mathrm{O},(33)(60,61)$ which precipitates when hydrofluoric acid is added to the solution. This material forms anhydrous nickel fluoride when heated to $350 \mathrm{C}$ in an atmosphere of dry hydrogen fluoride. If the material (either $\mathrm{NiF}_{2} \cdot 4 \mathrm{H}_{2} \mathrm{O}$ or $\mathrm{NiF}_{2}$ ) is heated in air, nickel oxide is formed. $(12,22)$

Berzelius $(1,2)$ makes a questionable claim that $\mathrm{NiF}_{2} \cdot 2 \mathrm{H}_{2} \mathrm{O}$ is formed by evaporation of nickel carbonate in excess hydrofluoric acid. Clarke(11) found crystals which were analyzed to be $\mathrm{NiF}_{2} \cdot 3 \mathrm{H}_{2} \mathrm{O}$. The more recent work, however, generally agrees with Costachescu, (33) who prepared the tetrahydrate (pale green, rhombic octahedra) by dissolving freshly precipitated nickel hydroxide in $40 \%$ hydrofluoric acid, diluting with an equal volume of acid, and allowing it to crystallize in vacuo over concentrated sulfuric acid.

Edmister and Cooper(34-36) found that a clear solution of nickel hydroxide or carbonate in excess hydrofluoric acid when evaporated in vacuo over sulfuric acid formed $\mathrm{NiF}_{2} \cdot 5 \mathrm{HF} \cdot 6 \mathrm{H}_{2} \mathrm{O}$ in small green prismatic crystals. Other workers were unable to confirm the experiment.

E. Reaction of Anhydrous $\mathrm{NiCl}_{2}$ with Hydrogen Fluoride

Ruff and Ascher(50) prepared nickel fluoride by the reaction of dry hydrogen fluoride with the anhydrous chloride. A similar method was employed by Hood and Woyski, (82) who studied the reaction

$$
\mathrm{HF}(\mathrm{g})+1 / 2 \mathrm{NiCl}_{2}(\mathrm{~s}) \Longrightarrow 1 / 2 \mathrm{NiF}_{2}(\mathrm{~s})+\mathrm{HCl}(\mathrm{g})
$$

They prepared the nickel chloride by recrystallizing reagent grade nickel chloride from a hydrochloric acid solution. The solid was dried at $300 \mathrm{C}$ in an atmosphere of anhydrous hydrogen chloride, then sublimed in a Vycor tube in a stream of hydrogen chloride. They then attempted to prepare nickel fluoride from the chloride by passing hydrogen fluoride over it in a fine silver tube from 100 to $500 \mathrm{C}$, but the reaction was incomplete. Their equilibrium data also suggest that this is not a good preparative method for nickel fluoride.

\section{F. Reaction of Nickel with Fluorine}

Fluorine reacts with nickel to produce the anhydrous fluoride. The product, however, forms a protective layer, so the reaction becomes too slow to serve as a practical preparative method. 


\section{G. Recovery from Fluorine Cells}

When fluorine is produced in an electrolytic cell, an anode sludge accumulates in the $\mathrm{KF} \cdot 2 \mathrm{HF}$ electrolyte. A means of recovering nickel from the sludge has been described.(92) The sludge is treated with an equal weight of water, filtered, and the filter cake is agitated with $23 \%$ ammonium hydroxide for 3 hours, filtered and washed. The filtrate is then evaporated 15 to 20 per cent to produce nickel fluoride, then to dryness, producing potassium and ammonium fluorides. The composition of the nickel compound is not given, but nickel fluoride is known to form hydrates, hydrofluorides and ammino complexes.

\section{H. Reaction of Nickel Oxide with Chlorine Trifluoride}

Farrar and Smith(106) in preparing nickel fluoride for chlorine trifluoride adsorption studies employed the reaction of nickel oxide with chlorine trifluoride. This reaction is said to produce a porous product.

\section{Decomposition of Hydrates and Double Salts}

The compounds $\mathrm{NiF}_{2} \cdot 4 \mathrm{H}_{2} \mathrm{O}$ and $\mathrm{NiF}_{2} \cdot 2 \mathrm{NH}_{4} \mathrm{~F}_{2} \cdot 2 \mathrm{H}_{2} \mathrm{O}$ can be decomposed thermally to form anhydrous nickel fluoride. An atmosphere of hydrogen fluoride is recommended, (108) although the reaction probably can be carried out in inert atmosphere. The presence of air, however, results in the formation of at least some nickel oxide.(12,22) Ruff and Ascher (50) prepared anhydrous nickel fluoride by melting nickel chloride with excess ammonium fluoride. The product, $\mathrm{NiF}_{2} \cdot 2 \mathrm{NH}_{4} \mathrm{~F}$, was heated in an inert gas stream, leaving behind anhydrous $\mathrm{NiF}_{2}$.

\section{THE POSSIBLE EXISTENCE OF HIGHER NICKEL FLUORIDES}

Although iron and cobalt both form the trifluorides, there is no instance in which nickel trifluoride has been reported. Cobalt trifluoride is prepared by the following reactions: $(70,85)$

$$
\begin{aligned}
& \mathrm{CoCl}_{2}+2 \mathrm{HF} \stackrel{350-450 \mathrm{C}}{\longrightarrow} \mathrm{CoF}_{2}+2 \mathrm{HCl} ; \\
& \mathrm{CoF}_{2}+1 / 2 \mathrm{~F}_{2} \stackrel{200-300 \mathrm{C}}{\longrightarrow} \mathrm{CoF}_{3}
\end{aligned}
$$

The amount of cobalt trifluoride formed can be determined by adding it to starch-iodide solution and titrating the liberated iodine with thiosulfate. Similar reactions, starting with nickel chloride, yield only $\mathrm{NiF}_{2}$. 
Although Simons $(76)$ states that $\mathrm{NiF}_{2}$ is the only compound of nickel and fluorine, and the preponderance of evidence certainly supports this view, there appears to be no particular case in which a concerted attempt has been made to prepare the trifluoride. Farrar and $\operatorname{Smith}(106)$ suggest the possibility of $\mathrm{NiF}_{3}$ formation in their chlorine trifluoride adsorption studies, but feel that it is unlikely. Barbieri and Calzolari(27) were unable to prepare the trifluoride by the electrolysis of $\mathrm{NiF}_{2}$ in a solution of fuming hydrofluoric acid.

The tetrafluoride of nickel has not been reported as such. However, the compound $\mathrm{K}_{2} \mathrm{NiF}_{6}$ has been prepared, in which $\mathrm{Ni}$ (IV) is apparently stabilized by the complex formation. This compound is discussed in Section VIII, Part A.

\section{HANDLING OF ANHYDROUS NICKEL FLUORIDE}

The consensus seems to be that anhydrous nickel fluoride does not react with air or atmospheric moisture at room temperature.(106) A sample of the material exposed to normal laboratory air gains weight slowly over a long period of time, but this is probably due to sorption of water vapor from the air, since it is removed by evacuation.(106) Priest(78) claims that anhydrous nickel fluoride is non-hygroscopic unless mixed with hydrated nickel fluoride. Kurtenacker, et al.,(60,61) also state that $\mathrm{NiF}_{2}, \mathrm{MnF}_{2}$ and $\mathrm{CdF} \mathrm{F}_{2}$ all show a similar reluctance to hydrate.

\section{PHYSICAL PROPERTIES}
A. Formula Weight: $96.69 \mathrm{~g} /$ mole
B. Description

Anhydrous nickel fluoride is a solid crystalline substance described variously as light yellow, (78) light greenish-yellow, (109) brownishgreen $(50)$ and green.(83)

\section{Melting Point and Vapor Pressure}

No direct determination of the melting point was found in the literature. Glassner(113) estimates a value of $1430 \mathrm{~K}$ (1157 C). Farber, et al.(114) state that it lies above $1365 \mathrm{~K}$ (1092 C). An extrapolated value of about $1250 \mathrm{C}$ might be inferred from the phase diagram of the system $\mathrm{KF}-\mathrm{NiF}_{\mathbf{2}} \cdot(86)$ 
In several of the earlier references $(18-20,22,24,76)$ it was stated that nickel fluoride can be sublimed at 1000 to $1200 \mathrm{C}$. More recently, the vapor pressure was determined experimentally over the range 1026 to $1349 \mathrm{~K}$, (114) yielding the equation

$$
\log P(\operatorname{atm} .)=6.8-\frac{13,100}{T(K)}
$$

The normal boiling point is estimated to lie slightly above $1950 \mathrm{~K}$ (1677 C). At the boiling point the estimated entropy of vaporization is $\leq 31 \mathrm{e} \cdot u$. The heat of sublimation from 1026 to $1349 \mathrm{~K}$ is $60 \pm 2 \mathrm{kcal} / \mathrm{mole}$.

Melting Point: $(1157,1250,>1092 \mathrm{C})$

Boiling Point: $1950 \mathrm{~K}(1677 \mathrm{C})$

D. Density

$4.63 \mathrm{~g} / \mathrm{cc}(22,83,111,112)$

$4.641 \mathrm{~g} / \mathrm{cc}(50)$

$4.60 \mathrm{~g} / \mathrm{cc}(44)$ at $25 \mathrm{C}$.

$4.814 \mathrm{~g} / \mathrm{cc}(102)$

The value of $4.63 \mathrm{~g} / \mathrm{cc}$ is probably considered to be the most reliable one. The last value $(4.814 \mathrm{~g} / \mathrm{cc})$ was obtained from $\mathrm{X}$-ray data on crystals grown from a nickel fluoride melt in contrast to the others, which were obtained from nickel fluoride prepared as the solid.

\section{E. Structure}

Anhydrous nickel fluoride forms tetragonal crystals (83) of the rutile type. The crystals are in the form of elongated prisms. The crystals are uniaxial positive, with $\omega=1.526$ and $\epsilon=1560$. Probably the best $\mathrm{X}$-ray data are those reported by Stout and $\operatorname{Reed}_{3}(103)$ who reported a rutile structure with space grouping $D_{4 h}^{14}-P 4 / m n m$. The following back reflection photographs were made:

\begin{tabular}{|c|c|c|c|c|c|}
\hline Radiation & $t(C)$ & $\begin{array}{l}\text { No. of } \\
\text { Lines }\end{array}$ & $a(\AA)$ & $c(\AA)$ & $\begin{array}{c}\text { avg dev } \\
\sin \theta\end{array}$ \\
\hline & 25 & 13 & $4.6505 \pm 0.0001$ & $3.0839 \pm 0.0003$ & 0.00010 \\
\hline copper & 24 & 12 & $4.6506 \pm 0.0002$ & $3.0832 \pm 0.0003$ & 0.00013 \\
\hline
\end{tabular}

In the rutile-type structure each unit cell contains two metal ions at positions $(0,0,0)$ and $(1 / 2,1 / 2,1 / 2)$ and four fluoride ions at $\pm(u, u, 0)$ and $\pm(1 / 2+u, 1 / 2-u, 1 / 2)$. 
The observed intensities of reflections in Debye photographs, for chromium $\mathbb{K} \alpha$ lines only, are as follows (on an arbitrary scale):

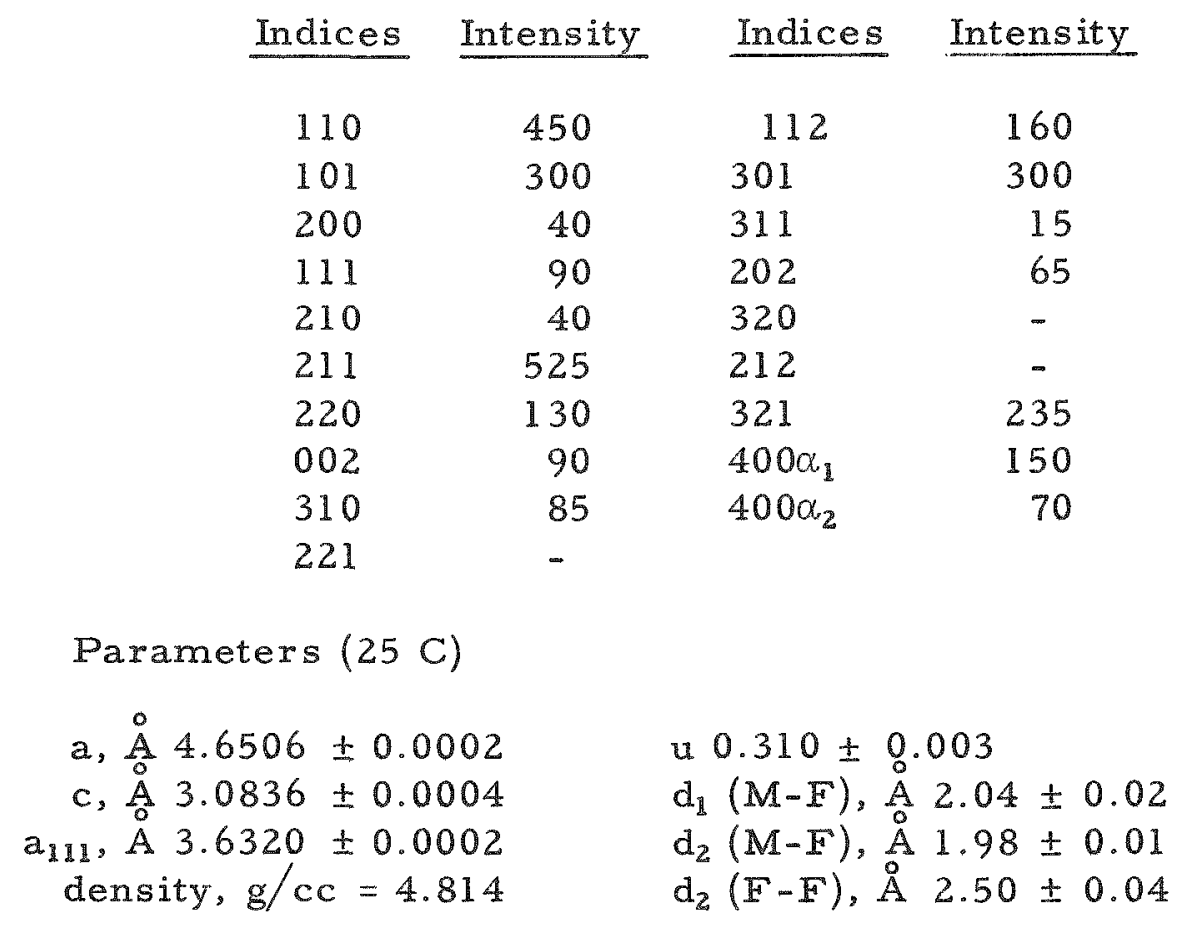

Each metal ion, $\mathrm{Ni}^{++}$, is surrounded by a distorted octahedron of $\operatorname{six} \mathrm{F}^{-}$ions. Two of these, at $\pm(u, u, 0)$, are at a distance $d_{\mathbb{I}}(M-F)$ and the remaining four are at the distance $\mathrm{d}_{2}(\mathbf{M}-\mathbf{F})$. The structure can be considered as a distortion of a structure with the fluoride ions arranged in a regular octahedron by compression of the a axes. In agreement with Pauling's explanation the values of $d(F-F)$ are all appreciably less than the crystal radius sum of $2.72 \AA$.

$\mathrm{X}$-ray identification of nickel fluoride has been reported by Hood and Woyski.(82)

\section{F. Magnetic Properties}

Elliott(108) has reported the following magnetic susceptibilities for nickel fluoride. Above 63K the Weiss-Curie Law applies:

$$
\chi_{\mathrm{mol}}=\frac{1.48}{\mathrm{~T}+154 \mathrm{~K}}
$$




$\begin{array}{cc}\left.\frac{T}{K}\right) & \chi_{\mathrm{mol}} \times 10^{6} \\ 61 & 8530 \\ 75 & 7600 \\ 163 & 4670 \\ 194 & 4240 \\ 295 & 3305 \\ 369 & 2825 \\ \mu_{\mathrm{Ni}}{ }^{++}= & 3.45 \beta\end{array}$

Other magnetic susceptibility data are given by Henkel and $\mathrm{Klemm}(63,64)$ Fereday, (57) Cabrera and Duperier, (55) Serres,(59) and de Haas et al.(69)

Neutron-diffraction studies on nickel fluoride(90) showed that below a critical temperature the compound begins to assume an ordered magnetic structure in which the magnetic moments of the ions at the body center and corner positions are coupled antiparallel. This ordering is evidenced by a progressive decrease in the paramagnetic diffuse scattering, and the simultaneous growth of superlattice peaks as the temperature is $x$ duced. The ionic magnetic moments appear to be aligned along one of the $F-N i-F$ directions so that $g_{100}^{2}=0.80$.

Matarrese and Stout $(101)$ found that nickel fluoride, unlike $\mathrm{MnF}_{2}, \mathrm{FeF}_{2}$ and $\mathrm{CoF}_{2}$, has a small magnetic moment below the Curie tem perature. Erickson(99) supports this view. The susceptibility of nickel. fluoride at room temperature was greater perpendicular to the tetragonal axis than parallel to it, and the difference between the perpendicular and parallel susceptibilities rose from $1.102 \times 10^{-4}$ at $301.15 \mathrm{~K}$ to $1.890 \times 10^{-4}$ at $90.07 \mathrm{~K} .(101)$ Below $73.2 \mathrm{~K}$ the observed torques were large and anomalous in their dependence on field strength and angle.(101) Erickson(99) interprets the small peak not found in the other antiferromagnetic fluorides of the iron group as an indication of ordered alignment; the spins, instead of being strictly parallel and antiparallel to the tetragonal axis as in $\mathrm{MnF}_{2}$, $\mathrm{FeF}_{2}$ and $\mathrm{CoF}{ }_{2}$, are in $\mathrm{NiF}_{2}$ inclined at an angle of $10^{\circ}$ from this axis. The effect is independent of sample purity. The powder neutron diffraction data cannot be interpreted to give more information than the inclination of the moment orientation with respect to the $c$ axis, but it is to be noted that this angle corresponds closely to the angle between the $c$ axis and either of the equivalent $F-N i-F$ directions. Thus the as sumption has been made that the moments are aligned along one of these lines. (99) The magnetic cell appears to be identical with the chemical cell.(99)

In connection with the presumed ordering at $73.2 \mathrm{~K}$ mentioned above, it is of interest to note that heat capacity data from 12 to $300 \mathrm{~K}(98)$ showed a pronounced lambda shaped thermal anomaly characteristic of 
cooperative ordering processes at $73,2 \mathrm{~K}$. These anomalies presumably represent an entropy loss upon passing from the disordered paramagnetic state to the ordered antiferromagnetic state.

Microwave studies (81) showed nickel fluoride to be one of the paramagnetic substances for which absorption peaks could not be found at room temperature with magnetic fields up to 15,000 gauss.

\section{G. Absorption Spectrum}

The absorption spectrum of nickel fluoride has been reporied by Deniges. $(40,41)$

\section{H. Toxicity}

The National Safety Council gives the maximum safe concentration of airborne nickel fluoride as $64 \mathrm{mg} / \mathrm{cu}$ meter. (111)

\section{CHEMICAL PROPERTIES - SOLUBILITIES AND SOLVATION}

\section{A. Hydrates}

Nickel fluoride has been reported in various states of hydration, viz. $\mathrm{NiF}_{2}, \mathrm{NiF}_{2} \cdot 2 \mathrm{H}_{2} \mathrm{O}, \mathrm{NiF}_{2} \cdot 3 \mathrm{H}_{2} \mathrm{O}$ and $\mathrm{NiF}_{2} \cdot 4 \mathrm{H}_{2} \mathrm{O}$.

Berzelius $(1,2)$ claims to have prepared $\mathrm{NiF}_{2} \cdot 2 \mathrm{H}_{2} \mathrm{O}$ by the evaporation of nickel carbonate in excess hydrofluoric acid, while Clarke(11) found crystals which were analyzed as $\mathrm{NiF}_{2} 3 \mathrm{H}_{2} \mathrm{O}$ (sp.gr. 2014 at $19 \mathrm{C}$ ). Neither of these hydrates has been reported since.

Costachescu(33) attempted to prepare the hexahydrate by treating nickel hydroxide with hydrofluoric acid and drying the product in vacuum over concentrated sulfuric acid, but he obtained $\mathrm{NiF}_{2} 4 \mathrm{H}_{2} \mathrm{O}$ instead. Ruff and Ascher(50) also mention the tetrahydrate as being the only stable one Kurtenacker, et al, $(60,61)$ in obtaining solubility data on nickel fluoride in water also characterized the solid phase as $\mathrm{NiF}_{2} \cdot 4 \mathrm{H}_{2} \mathrm{O}$

In the light of this and much more recent work, it seems fairly clear that the only species are anhydrous $\mathrm{NiF}_{2}$ and the tetrahydrate $\mathrm{NiF}_{2} \cdot 4 \mathrm{H}_{2} \mathrm{O}$. Anhydrous nickel fluoride exposed to atmospheric moisture appears to take up water only by physical adsorption

\section{B. Solubility in Water}

Most of the solubility data in the literature $(50,83,111)$ agree with the values reported by Kurtenacker. (60,61) He found the solid phase to be $\mathrm{NiF}_{2} \cdot 4 \mathrm{H}_{2} \mathrm{O}$. 


$\begin{array}{rr}\mathrm{T}(\mathrm{C}) & \mathrm{g} \mathrm{NiF}_{2} / 100 \mathrm{~g} \mathrm{H}_{2} \mathrm{O} \\ 10 & 2.49 \\ 25 & 2.50 \\ 50 & 2.50 \\ 100 & 2.52\end{array}$

The solubility appears to be nearly independent of the temperature. A solubility figure of $4.030 \mathrm{~g} \mathrm{NiF}_{2} / 100 \mathrm{ml}$ saturated solution reported by Carter $(47)$ and sometimes quoted elsewhere is probably erroneous.

Aqueous solutions of nickel fluoride are said to decompose on boiling with the formation of a basic fluoride $2 \mathrm{NiF}_{2} \cdot 2 \mathrm{NiO} \cdot \mathrm{H}_{2} \mathrm{O} .(76)$

The anhydrous salt, according to Ruff and Ascher, $(50)$ is considerably less soluble than the hydrated form, with a value of $0.02 \mathrm{~g} \mathrm{NiF}_{2} /$ $100 \mathrm{~g} \mathrm{H}_{2} \mathrm{O}$ at $25 \mathrm{C}$. Poulenc $(22)$ also states that the anhydrous salt is nearly insoluble.

\section{Solubility in Hydrogen Fluoride and Hydrofluoric Acid}

Jache and Cady (95) obtained an indication that no solid phase complex is formed when anhydrous nickel fluoride is immersed in liquid hydrogen fluoride. Their solubility data are as follows:

$\begin{array}{cc}\mathrm{T}(\mathrm{C}) \\ \begin{array}{r}-25.0 \\ -9.7\end{array} & \mathrm{~g} \mathrm{NiF}_{2} / 100 \mathrm{~g} \mathrm{HF} \\ 11.9 & 0.035 \\ & 0.040 \\ & 0.037\end{array}$

No compound of nickel fluoride and hydrogen fluoride was found when solid nickel fluoride was exposed to anhydrous hydrogen fluoride vapor.

In hydrofluoric acid solutions the solubility of nickel fluoride increases as the hydrofluoric acid concentration is raised, $(60,61)$ The solid phase is $\mathrm{NiF}_{2} \cdot 4 \mathrm{H}_{2} \mathrm{O}$.

\begin{tabular}{rrr} 
Temp. 20C & HF, \% & Solubility, \% \\
\cline { 2 - 3 } & 0 & 2.50 \\
9.25 & 7.73 \\
12.39 & 10.02 \\
17.46 & 11.45 \\
30.10 & 13.30
\end{tabular}


The compound $\mathrm{NiF} \cdot 5 \mathrm{HF} \cdot 6 \mathrm{H}_{2} \mathrm{O}$ was reported by Bohm $(30)$ and by Edmister and Cooper, $(34-36)$ who evaporated clear solutions of nickel hydroxide and nickel carbonate in excess hydrofluoric acid in vacuum over sulfuric acid. Other workers have not been able to repeat the experiment. It is reported as being in the form of green prismatic crystals (trigonal) with $\alpha=112^{\circ} 1^{\prime}$ and sp. gr。2.132.

\section{Miscellaneous Solubility Data}

Nickel fluoride is said to be "soluble" in aqueous solutions of potassium cyanide, (83) ammonium fluoride(23) and hydrofluoric acid.60,61,83) Poulenc (22) claims that nickel fluoride is converted to the chloride when heated in hydrogen chloride, but that it is unaffected by hot hydrochloric acid. Gore, $(9,10)$ however, mentions aqueous solutions of nickel fluoride in hydrochloric acid. It is unattacked by warm sulfuric or nitric acids.(22) Boiling 12 per cent acetic acid attacks it only slightly.(50) Nickel fluoride is insoluble in liquid ammonia, $(9,10)$ alcohol, $(22,83)$ benzene and ether. (22) The tetrahydrate can be dissolved in pyridine, forming a complex compound.(33)

In liquid bromine trifluoride the solubility of nickel fluoride is reported to be less than $0.003 \mathrm{~g} / 100 \mathrm{~g} \mathrm{BrF}_{3}$ at $25 \mathrm{C}$ and less than $0.002 \mathrm{~g} /$ $100 \mathrm{~g} \mathrm{BrF}_{3}$ at $70 \mathrm{C}$ (100)

\section{CHEMICAL PROPERTIES - ADSORPTION OF GASES}

\section{A. Sorption of Chlorine Trifluoirde}

Farrar and Smith(106) reported studies on the adsorption of chlorine trifluoride by anhydrous nickel fluoride. The nickel fluoride was prepared by the action of chlorine trifluoride on nickel oxide, which is said to yield a porous form of the product.

The reaction was observed by means of pressure-volume relationships and by weight increase of the sample. The nickel fluoride powder was loaded into the system and evacuated to constant weight at 125 to $150 \mathrm{C}$ and a pressure less than $10^{-4} \mathrm{~mm}$. After degassing, the container was weighed, then exposed to chlorine trifluoride. At frequent time intervals the container was removed and weighed.

It was found that the chlorine trifluoride was adsorbed rapidly at first, then slowly. Even after 100 hours it was not possible to extrapolate to a saturation value. Data at $28.2 \mathrm{C}$ are as follows: 


\begin{tabular}{ccc}
$\begin{array}{c}\text { Exposure Time } \\
(\mathrm{hr})\end{array}$ & $\begin{array}{c}\mathrm{ClF}_{3} \text { Sorbed }\left(\mathrm{G}_{\mathrm{T}}\right) \\
(\mathbf{m g} / \mathrm{g})\end{array}$ & $\mathrm{y}=\mathrm{G}_{\mathrm{T}}-20.0$ \\
\cline { 1 - 2 } 1.4 & 15.9 & \\
2.3 & 19.7 & \\
19.6 & 20.1 & 0.1 \\
27.0 & 22.1 & 2.1 \\
48.6 & 22.7 & 2.7 \\
67.6 & 23.7 & 3.7 \\
92.5 & 24.6 & 4.6 \\
& 25.1 & 5.1
\end{tabular}

They concluded that the sorption was a physical process. It was reversible by evacuation at room temperature. A chemical process might form an addition complex, or possibly nickel trifluoride, but neither is believed likely. X-ray patterns could not be obtained due to the high reactivity of the material.

The data generally fit Langmuir adsorption isotherms well. There appear to be two regions: (1) a rapid initial rate due to filling of the pores in the solid by chlorine trifluoride, and (2) a slower rate, which is a surface phenomenon. When the low temperature (-195 C) BET method was used with nitrogen, the area of the fluoride was found to be strongly dependent upon the degassing treatment.

Surface Area ( $\mathrm{sq} \mathrm{m} / \mathrm{g}$ )

Sample 1 (1-wk exposure to laboratory air)

1. 16-hr evacuation at $\mathrm{rm}$ temp

25.8

2. 16-hr evacuation at $\mathrm{rm}$ temp $+2 \mathrm{hr}$ at $150 \mathrm{C} \quad 34.2$

3. 16-hr evacuation at $\mathrm{rm}$ temp $+2 \mathrm{hr}$ at $200 \mathrm{C} \quad 36.8$

4. 16-hr evacuation at $\mathrm{rm}$ temp $+2 \mathrm{hr}$ at $230 \mathrm{C} \quad 36.9$

Sample 2 ( 1 -wk exposure to laboratory arr)

1. 16-hr evacuation at $\mathrm{rm}$ temp $+2 \mathrm{hr}$ at $150 \mathrm{C} \quad 33.0$

2. 2.5-day exposure to lab air $+16 \mathrm{chr}$ evacuation $\quad 28.9$ at room temp

These values are somewhat lower than those reported elsewhere, but are in reasonable agreement considering the different methods of preparation of nickel fluoride. 
VIII. CHEMICAL PROPERTIES - REACTIONS OF NICKEL FLUORIDE

\section{A. Reaction with Hydrogen Chloride}

An equilibrium study was made by Hood and Woyski(82) of the following reaction:

$$
\mathrm{HF}(\mathrm{g})+1 / 2 \mathrm{NiCl}_{2}(\mathrm{~s}) \underset{\mathrm{b}}{\stackrel{\mathrm{a}}{\longrightarrow}} 1 / 2 \mathrm{NiF}_{2}(\mathrm{~s})+\mathrm{HCl}(\mathrm{g}) \text {. }
$$

The nickel chloride was prepared by recrystallizing reagent grade nickel. chloride from hydrochloric acid solution and drying at $300 \mathrm{C}$ in a stream of anhydrous hydrogen chloride. The product was resublimed in a Vycor tube in anhydrous hydrogen chloride. The nickel fluoride was prepared by treating the nickel chloride with hydrogen fluoride from 100 to $500 \mathrm{C}$. The reaction was incomplete, however.

The equilibrium of the reaction above was studied over the range 477 to $833 \mathrm{~K}$. X-ray identification was used for the solid compounds.

\begin{tabular}{ccccc} 
T, K & Direction of Reaction & & & \multicolumn{1}{c}{$\Delta$, cal } \\
477 & a & & 0.2262 & 1410 \\
520 & $\mathrm{~b}$ & 0.2633 & 1380 \\
589 & $\mathrm{a}$ & 0.3055 & 1390 \\
623 & $\mathrm{~b}$ & 0.3197 & 1410 \\
684 & $\mathrm{a}$ & 0.3620 & 1380 \\
735 & $\mathrm{~b}$ & 0.3755 & 1430 \\
801 & $\mathrm{a}$ & 0.4093 & 1420 \\
833 & $\mathrm{~b}$ & 0.4288 & 1400
\end{tabular}

The mean values at $680 \mathrm{C}$ are: $\Delta F=+1400 \mathrm{cal}: \Delta \mathrm{H}=+1390 \mathrm{cal}$; $\Delta S=-0.02 \mathrm{e} . u$. The probable error in $\Delta F= \pm 56$ cal. Their conclusion is that nickel fluoride is a relatively poor fluorinating agent.

\section{B. Reaction with Hydrogen}

Hydrogen will reduce nickel fluoride to the metal at elevated temperatures. $(22,45)$ The equilibrium of the following reaction was studied by Jellinek and Rudat:(45)

$$
\begin{gathered}
\mathrm{NiF}_{2}(\mathrm{~s})+\mathrm{H}_{2}(\mathrm{~g}) \rightleftarrows \mathrm{Ni}(\mathrm{s})+2 \mathrm{HF}(\mathrm{g}) . \\
\mathrm{K}=\frac{\mathrm{P}^{2} \mathrm{HF}}{\mathrm{P}_{\mathrm{H}_{2}}}
\end{gathered}
$$




\begin{tabular}{|c|c|}
\hline$T, \quad C$ & $\mathrm{~K}$, atm \\
\hline 300 & 0.0033 \\
\hline 400 & 0.1380 \\
\hline 450 & 0.5495 \\
\hline 500 & 2.09 \\
\hline
\end{tabular}

The forward reaction proceeds readily to equilibrium, while the reverse reaction is inhibited by the formation of a nickel fluoride film on the metal surface.

\section{Reaction with Ammonia} the metal. (50)

At elevated temperatures ammonia reduces nickel fluoride to

At lower temperatures, however, Clark(37) obtained nickel hexamminofluoride, $\mathrm{NiF}_{2} \cdot 6 \mathrm{NH}_{3}$, by the reaction of anhydrous nickel fluoride with ammonia.

D. Reaction with Air

Poulenc(22) and Schulze(12) found that nickel fluoride is converted to the oxide when heated strongly in air.

\section{E. Reaction with Water Vapor}

Nickel fluoride when heated in water vapor forms the black oxide, and at higher temperatures, green nickelous oxide. (22)

F. Reaction with Sulfur Compounds

Sulfur and hydrogen sulfide convert nickel fluoride to the sulfide on heating.(22) At red heat sulfur dioxide darkens crystals of nickel fluoride, but the product was not identified. (50)

\section{G. Reaction with Halogens}

Nickel fluoride is not attacked by bromine or iodine.(50) No information appears to be available on chlorine.

H. Reaction with Phosphorus and Arsenic

No reaction was obtained on treating nickel fluoride with red phosphorus or arsenic. (50) 


\section{Reaction with Carbon and Silicon}

Carbon does not react with nickel fluoride.(50) Silicon, however, when heated with nickel fluoride reacts vigorously below red heat. $(9,10,50)$ The product is not identified.

\section{J. Reaction with Metals}

Nickel fluoride reacts vigorously upon heating with sodium, magnesium, aluminum and zinc, but not with copper or iron. (50) The reaction products are not identified.

K. Reaction with Alkali Metal Oxides and Hydroxides

When heated in alkali, nickel fluoride forms nickel oxide (NiO) and alkali fluoride.(22) A boiling solution of 33 per cent sodium hydroxide converts nickel fluoride to an unidentified green liquid.(50)

\section{Reaction with Fluorides}

When nickel fluoride is fused with potassium fluoride $(86,96)$ or ammonium fluoride, $(23)$ complex addition compounds are produced. These are discussed in a later section.

\section{CHEMICAL PROPERTIES - COMPLEX COMPOUNDS}

\section{A. Alkali Metal Fluorides}

$\mathrm{NaF} \cdot \mathrm{NiF}_{2} \cdot \mathrm{H}_{2} \mathrm{O}$ Wagner $(14)$ claims to have prepared $\mathrm{NaF} \cdot \mathrm{NiF}{ }_{2} \cdot$ $\mathrm{H}_{2} \mathrm{O}$ by evaporation of a solution of the component salts. The composition, however, is not well established.

\section{$\mathrm{KF} \cdot \mathrm{NiF}_{2}$ Goldschmidt(42) prepared $\mathrm{KNiF}_{3}$ by the fusion of} potassium fluoride and nickel fluoride in a blast lamp. The melting point is $1130+2 \mathrm{C} .(86)$ The compound crystallizes with the perovskite structure and might be considered a double halide, since the lattice consists of $\mathrm{K}^{+}$, $\mathrm{Ni}^{++}$and $\mathrm{F}^{-}$ions. The unit cell is cubic with $\mathrm{K}^{+}$ions at the corners, a $\mathrm{Ni}^{+t}$ ion at the center, and $\mathrm{F}^{-}$ions at the centers of the faces.

$\mathrm{KF} \cdot \mathrm{NiF}_{2} \cdot \mathrm{H}_{2} \mathrm{O}$ According to Berzelius $(1,2)$ and Wagner $(14)$ this compound is formed as a yellow powder, or in apple-green crystals, by evaporation of a solution of the component salts. Kurtenacker, et al., $(60,61)$ studied the equilibrium $\mathrm{NiF}_{2}-\mathrm{KF}-\mathrm{H}_{2} \mathrm{O}$ at $20 \mathrm{C}$ and $50 \mathrm{C}$. At $20 \mathrm{C}$ the solubilities, $\mathrm{S} g$ salt $/ 100 \mathrm{~g}$ solution, are as follows: 


$\begin{array}{lllllcc}\mathrm{KF} & 1.21 & 3.52 & 6.32 & 9.64 & 12.9 & 16.8 \\ \mathrm{NiF}_{2} & 1.98 & 1.20 & 0.80 & 0.52 & 0.40 & 0.01\end{array}$

$2 \mathrm{KF} \cdot \mathrm{NiF}_{2}$ Poulenc(19) first prepared the compound $\mathrm{K}_{2} \mathrm{NiF}_{4}$ by heating anhydrous nickel fluoride to about $200 \mathrm{C}$ with potassium bifluoride. The product was imbedded in the potassium chloride as large green quadratic plates with a density of $3.27 \mathrm{~g} / \mathrm{cc}$. More recently Wagner and Balz $(86)$ obtained $\mathrm{K}_{2} \mathrm{NiF}_{4}$ as the initial solid phase on cooling a potassium fluoridenickel fluoride melt with a nickel fluoride content between 9.2 and 23.3 mole per cent. $\mathrm{X}$-ray work by $\mathrm{Balz}(96)$ indicates tetragonal structure with $\mathrm{a}=$ $\mathrm{b}=4.00 \mathrm{~A} ; \mathrm{c}=13.06 \mathrm{~A}$; density $3.37 \mathrm{~g} / \mathrm{cc}$. The compound melts at $930 \mathrm{C}$ with decomposition. It is soluble in water and in cold hydrofluoric, hydrochloric and nitric acids. Ammonium hydroxide solution colors it blue. On heating in air the potassium fluoride volatilizes and nickel oxide remains behind.

Phase Diagram: KF $-\mathrm{NiF}_{2}$ The phase diagram of the system

Figure 1

PHASE DIAGRAM KF-NiF 2

Source: G. Wagner and D. $\mathrm{Balz}^{(86)}$

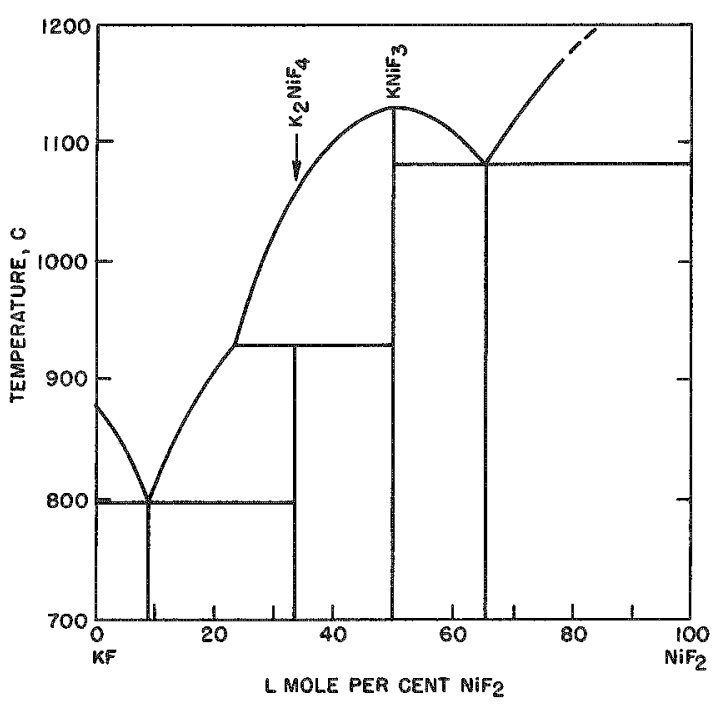

potassium fluoride-nickel fluoride was investigated, with respect to a $\mathrm{BaO}-$ $\mathrm{TiO}_{2}$ model, using $\mathrm{X}$-ray and thermal analysis techniques.(86) The diagram is shown in Figure 1. The compounds $\mathrm{K}_{2} \mathrm{NiF}_{4}$ and $\mathrm{KF}$ form a eutectic mixture at 9.1 mole per cent nickel fluoride, with a melting point of $797 \mathrm{C}$. The eutectic between $\mathrm{KNiF}_{3}$ and $\mathrm{NiF}_{2}$ lies at 65.5 mole per cent nickel fluoride and has a melting point of $1084 \mathrm{C}$. The compound $\mathrm{K}_{2} \mathrm{NiF}_{4}$ melts incongruently at $930 \mathrm{C}$ with decomposition into $\mathrm{KNiF}_{3}$ and a $\mathbb{K F}-\mathrm{NiF}_{2}$ melt containing 23.3 mole per cent nickel fluoride. The melting point of nickel fluoride was not determined, but it might be inferred from the diagram that it lies in the vicinity of $1250 \mathrm{C}$.

$\mathrm{K}_{2} \mathrm{NiF}_{6}$ This compound, containing tetravalent nickel, is prepared by fluorination of a mixture of potassium chloride and nickel chloride.(74) A homogeneous mixture of two moles of potassium chloride per mole of nickel chloride was heated about 3 hours. The product is light red. The weight change corresponds to the formation of $\mathrm{K}_{2} \mathrm{NiF}_{6}$ with the following analytical data: 


\begin{tabular}{|c|c|c|c|}
\hline & $\mathbf{K}$ & $\mathrm{Ni}$ & $\mathrm{KF}$ \\
\hline Calculated & 31.16 & 23.40 & 45.44 \\
\hline Observed & 312 & 23.5 & 44.7 \\
\hline
\end{tabular}

The $\mathrm{X}$-ray diagram confirmed the structure $\mathrm{K}_{2} \mathrm{NiF}_{6}$, which was cubic, similar to $K_{2} S_{i F}$. The $X$-ray density is $3.10 \mathrm{~g} / \mathrm{cc}$, while direct pycnometric determinations gave $3.03 \mathrm{~g} / \mathrm{cc}$. The material reacts with water, evolving a gas which it is believed may be $\mathrm{OF}_{2}$.

\section{B. Ammonia and Ammonium Fluoride}

$\mathrm{NiF}_{2} \cdot 6 \mathrm{NH}_{3}$ An addition compound resulting from the action of ammonia on anhydrous nickel fluoride was reported by Clark.(37) The material is a dark greyish-violet powder.

$\mathrm{NiF}_{2} \cdot 1 / 2 \mathrm{NH}_{3} \cdot \mathrm{H}_{2} \mathrm{O}$ Biltz and Rahlfs $(44)$ reported this and the two following compounds as products of the simultaneous reaction of water vapor and ammonia with nickel fluoride. The specific gravity is 2.820 .

$\mathrm{NiF}{ }_{2} \cdot \mathrm{NH}_{3} \cdot \mathrm{H}_{2} \mathrm{O}$ This compound, formed by the reaction above, has a specific gravity of 2.489 and the following vapor pressures: $10.0 \mathrm{~mm}$ at $34.5 \mathrm{C} ; 22.5 \mathrm{~mm}$ at $46.5 \mathrm{C} ; 55 \mathrm{~mm}$ at $61 \mathrm{C}$. The vapor phase composition is not given.

$\mathrm{NiF}_{2} \cdot 5 \mathrm{NH}_{3} \cdot \mathrm{H}_{2} \mathrm{O}$ Biltz and Rahlfs (44) obtained a blue oil from the reaction of water vapor and ammonia with nickel fluoride. It was also prepared by cooling in dry ice a mixture of $40 \mathrm{cc}$ of boiled alcohol with a solution of $6 \mathrm{~g} \mathrm{NiF} 2.4 \mathrm{H}_{2} \mathrm{O}$ in $25 \mathrm{cc}$ of concentrated ammonium hydroxide. The specific gravity is 1.576 at $25 \mathrm{C}$ and the following vapor pressures are given:

$\begin{array}{crr}\frac{T,(\mathrm{C})}{0} & & \text { P }(\mathrm{mm}) \\ 18 & & 4.8 \\ 35 & & 50.0 \\ 465 & & 102.5 \\ 61.5 & & 245.5\end{array}$

$5 \mathrm{NiF}_{2} \cdot 6 \mathrm{NH}_{3} \cdot 8 \mathrm{H}_{2} \mathrm{O}$ Bohm $(30)$ claims that excess ammonium hydroxide and nickel fluoride form a solution, which, on evaporation over potassium hydroxide, forms an oily liquid with pale green crystals of $5 \mathrm{NiF}_{2} 6 \mathrm{NH}_{3} \cdot 8 \mathrm{H}_{2} \mathrm{O}$. The salt is insoluble in cold water, decomposed by boiling water, and soluble in dilute acids. When heated in the open, the crystals lost water, then ammonium fluoride, and nickel oxide remained behind. 
$2 \mathrm{NH}_{4} \mathrm{~F} \cdot \mathrm{NiF}_{2}$ Poulenc(22) prepared anhydrous $\left(\mathrm{NH}_{4}\right)_{2} \mathrm{NiF}_{4}$ by fusing together anhydrous nickel chloride and excess ammonium fluoride and leaching out the ammonium chloride with boiling alcohol. The product is an amorphous yellow powder, soluble in water. When heated to redness in an inert gas stream, the material gives off ammonium fluoride, leaving behind anhydrous nickel fluoride.

$2 \mathrm{NH}_{4} \mathrm{~F} \cdot \mathrm{NiF}_{2} \cdot 2 \mathrm{H}_{2} \mathrm{O}$ Berzelius $(1,2)$ and Wagner $(14)$ prepared the dehydrate from a mixed solution of the component salts. H. von Helmholt(23) prepared it by evaporating slowly a solution of nickel hydroxide in a hot, neutral ammonium fluoride solution. The compound consists of pale green or yellow crystals isomorphous with those of the corresponding cobalt salt. They are readily soluble in water. Kurtenacker and associates $(60,61)$ investigated equilibrium conditions in the system $\mathrm{NiF} \cdot \mathrm{NH}_{4} \mathrm{~F} \cdot \mathrm{H}_{2} \mathrm{O}$ at $20 \mathrm{C}$ and $25 \mathrm{C}$. Their data at $20 \mathrm{C}$, where $\mathrm{S}$ is the solubility in $\mathrm{g}$ salt $/ 100 \mathrm{~g}$ solution, are as follows:

$\begin{array}{llllll}\mathrm{NH}_{4} \mathrm{~F} & 0 & 3.4 & 6.4 & 9.4 & \\ \mathrm{~S}\left(\mathrm{NiF}_{2}\right) & 2.50 & 1.07 & 0.91 & 0.72 & \\ & & \text { (solid phase: } & \left.\mathrm{NiF}_{2} \cdot 4 \mathrm{H}_{2} \mathrm{O}\right) & \\ \mathrm{NH}_{4} \mathrm{~F} & 10.4 & 17.1 & 23.0 & 31.1 & 37.4 \\ \mathrm{~S}\left(\mathrm{NiF}_{2}\right) & 0.51 & 0.17 & 0.07 & 0.01 & 0.01 \\ & \text { (solid phase: } & 2 & \mathrm{NH}_{4} \mathrm{~F} \cdot \mathrm{NiF}_{2} \cdot 2 & \left.\mathrm{H}_{2} \mathrm{O}\right) & \end{array}$

C. Beryllium and Aluminum

$\mathrm{BeF}_{2} \cdot \mathrm{NiF}_{2} \cdot 7 \mathrm{H}_{2} \mathrm{O}$ Ray and Sarkar (52) prepared this compound, which is analogous to $\mathrm{NiSO}_{4} \cdot 7 \mathrm{H}_{2} \mathrm{O}$, by adding nickel nitrate to the theoretical amount of ammonium fluoberyllate.

$\mathrm{AlF}_{3} \cdot \mathrm{NiF}_{2} \cdot 7 \mathrm{H}_{2} \mathrm{O}$ Weinland and $\mathrm{Kopppen}(25)$ found that the evaporation of solution of aluminum hydroxide with nickel hydroxide or nickel carbonate in dilute hydrofluoric acid at room temperature over lime forms this compound. The small green crystals are sparingly soluble in hydrofluoric acid. Berzelius $(1,2)$ evaporated a mixed solution of nickel and aluminum fluorides and obtained long, pale apple-green crystals which dissolved slowly in water. Their identity was not established, however.

\section{Tin, Titanium, Zirconium and Cerium Fluorides}

$\mathrm{SnF}_{4} \cdot \mathrm{NiF}_{2} \cdot 6 \mathrm{H}_{2} \mathrm{O} \mathrm{J}$. de Marignad $(3,5,6)$ reported this compound, which is soluble in water.

$\mathrm{TiF}_{4} \cdot \mathrm{NiF}_{2} \cdot 6 \mathrm{H}_{2} \mathrm{O}$ This compound was prepared by Weber, (7) who dissolved titanium dioxide and nickel oxide in hydrofluoric acid. The green crystals are water-soluble. 
$\mathrm{ZrF}_{4} \cdot \mathrm{NiF}_{2} \cdot 6 \mathrm{H}_{2} \mathrm{O}$ This compound, analogous to the two above, was prepared by de Marignac. $(3,5,6)$ It is water-soluble.

$\mathrm{ZrF}_{4} \cdot 2 \mathrm{NiF}_{2} \cdot 12 \mathrm{H}_{2} \mathrm{O}$ This compound, also reported by de Marignac, $(3,5,6)$ is water-soluble.

$2 \mathrm{CeF}_{4} \cdot \mathrm{NiF}_{2} \cdot 7 \mathrm{H}_{2} \mathrm{O}$ Rimbach and Killian, (32) on mixing a solution of ceric and nickelous hydroxides with hydrofluoric acid, obtained apple-green crystals which they identified as this compound.

E. Vanadium and Niobium Fluorides

$\mathrm{VF}_{3} \cdot \mathrm{NiF}_{2} \cdot 7 \mathrm{H}_{2} \mathrm{O}$ Peterson $(15 ; 16)$ reported this salt as the product obtained on the evaporation of a solution of vanadium trifluoxide and nickel carbonate in hydrofluoric acid. The crystals are monoclinic with a prism angle of $57^{\circ} 45^{\circ}$. It is isomorphous with the corresponding cobalt salt and loses water on heating to $200 \mathrm{C}$ but not at $100 \mathrm{C}$.

VOF $2 \cdot \mathrm{NiF}_{2} \cdot 7 \mathrm{H}_{2} \mathrm{O}$ This material was prepared by Piccini and Georgis, $(17,21)$ who dissolved vanadic acid and somewhat less than the required molar proportion of nickel carbonate in hydrofluoric acid. When the solution is intensely blue colored it is filtered and evaporated. The green crystals are isomorphous with the cobalt salt. this compound.

$2 \mathrm{NbF}_{5} \cdot 3 \mathrm{NiF}_{2} \cdot 4 \mathrm{HF} \cdot 19 \mathrm{H}_{2} \mathrm{O}$ Streng(8) claims to have prepared

F. Chromium, Molybdenum and Tungsten Fluorides

$\mathrm{CrF}_{3} \cdot \mathrm{NiF}_{2} 7 \mathrm{H}_{2} \mathrm{O}$ Peterson $(15,16)$ prepared this substance by evaporating a mixed solution of chromic fluoride and nickel carbonate in hydrofluoric acid. The emerald-green crystals are monoclinic with a prism angle of $57^{\circ} 25^{\prime}$. It is isomorphous with the cobalt salt and loses water at $200 \mathrm{C}$, but not at $100 \mathrm{C}$.

$\mathrm{MoO}_{2} \mathrm{~F}_{2} \cdot \mathrm{NiF}_{2} \cdot 6 \mathrm{H}_{2} \mathrm{O}$ This compound was reported by Delafontaine $(4)$ by the evaporation of a solution of nickel and molybdenum oxides in hydrofluoric acid.

$\mathrm{WO}_{2} \mathrm{~F}_{2} \cdot \mathrm{NiF}_{2} \cdot 6 \mathrm{H}_{2} \mathrm{O}$ This substance was prepared by Delafontaine $(4)$ by the same method given for the preceding molybdenum compound.

$\mathrm{WO}_{2} \mathrm{~F}_{2} \cdot \mathrm{NiF}_{2} \cdot 10 \mathrm{H}_{2} \mathrm{O} \mathrm{J}$. de Marignac $(3,5,6)$ reported the higher hydrate of the compound as consisting of deliquescent crystals. 
G. Iron Fluoride and Nickel Oxide and Koppen. $(25)$

$\mathrm{FeF}_{3} \cdot \mathrm{NiF}_{2} \cdot 7 \mathrm{H}_{2} \mathrm{O}$ This compound was reported by Weinland

$2 \mathrm{NiO} \cdot 2 \mathrm{NiF}_{2} \cdot \mathrm{H}_{2} \mathrm{O}$ Berzelius $(1,2)$ reported this substance as the result of evaporating a solution of excess nickel carbonate or of boiling hydrated nickel fluoride crystals in water. It is a pale green color.

H. Miscellaneous

$\mathrm{Ni}\left(\mathrm{H}_{2} \mathrm{O}\right)_{2} \mathrm{Py}_{4} \mathrm{~F}_{2} \cdot \mathrm{H}_{2} \mathrm{O}$ Costachescu(33) prepared azure blue crystals of nickelous diaquotetrapyridine fluoride by dissolving hydrated nickel fluoride in pyridine.

[Ni(antipyr $\left.)_{6}\right]\left(\mathrm{BF}_{4}\right)_{2}$ Nickel antipyrinefluoborate was reported by Wilke-Dörfurt and Mureck. (51)

\section{THERMOCHEMICAL DATA}

A critical evaluation of the various thermochemical values reported for nickel fluoride would involve a considerable amount of time and effort. Therefore, some of the various values are reported, followed by the data of Glassner, (113) which are presumably the result of such an evaluation.

The heat of formation of nickel fluoride $\left(\mathrm{NiF}_{2}\right.$, aq. $)$ is given as $-171.4 \mathrm{kcal} / \mathrm{mole}$ (39) Rudat $(46)$ gives a value of $-157.5 \mathrm{kcal} / \mathrm{mole}\left(\mathrm{NiF}_{2}, \mathrm{c}\right.$ ) at 300 to $500 \mathrm{C}$. Peterson $(15,16)$ gives the heat of formation $\left(\mathrm{NiF}_{2}\right.$, aq.) as $-122.8 \mathrm{kcal} / \mathrm{mole}$ and the heat of neutralization for the following reaction as $18.835 \mathrm{kcal} / \mathrm{mole} \mathrm{HF}$ :

$$
1 / 2 \mathrm{Ni}(\mathrm{OH})_{2}+\mathrm{HF}(\mathrm{aq}) \longrightarrow 1 / 2 \mathrm{NiF}_{2}(\mathrm{aq}) .
$$

Rossini (93) lists the heat of formation for $\left(\mathrm{NiF}_{2}, \mathrm{c}\right)$ as $-159.5 \mathrm{kcal} / \mathrm{mole}$ at $298.16 \mathrm{~K}$. Brewer $(79)$ and Kellogg(84) give the following free energy values for $\left(\mathrm{NiF}_{2}, \mathrm{c}\right)$ :

\begin{tabular}{|c|c|}
\hline Temperature & $(\mathrm{K})$ \\
\hline $\begin{array}{l}298.16 \\
500\end{array}$ & \\
\hline 1000 & \\
\hline 1500 & \\
\hline
\end{tabular}

\begin{tabular}{c}
$\begin{array}{c}\text { Standard Free Energy } \\
(\mathrm{kcal} / \mathrm{mole})\end{array}$ \\
\hline-147.3 \\
-140.0 \\
-124.0 \\
-108.5
\end{tabular}


The standard free energy change for the reaction

$$
\mathrm{NiO}(\mathrm{c})+\mathrm{F}_{2}(\mathrm{~g}) \longrightarrow \mathrm{NiF}_{2}(\mathrm{c})+\frac{1}{2} \mathrm{O}_{2}(\mathrm{~g})
$$

is reported as follows: (84)

$$
\text { Temperature, }(K)
$$

25

500

1000
Standard Free Energy

( $\mathrm{kcal} / \mathrm{mole})$

$-94.7$

$-88.7$

$-83.5$

The following values are given for the reaction

$$
\begin{array}{cc}
\mathrm{NiCl}_{2}(\mathrm{c})+\mathrm{F}_{2}(\mathrm{~g}) \longrightarrow \mathrm{NiF}_{2}(\mathrm{c})+\mathrm{Cl}_{2}(\mathrm{~g}): \\
\begin{array}{c}
\text { Standard Free Energy } \\
(\mathrm{kcal} / \mathrm{mole})
\end{array} \\
\cline { 2 - 2 } 25 & -82.2 \\
500 & -81.8 \\
1000 & -81.4
\end{array}
$$

Farber, et al.(114)list the normal boiling point as slightly above $1950 \mathrm{~K}$, where the entropy of vaporization is estimated to be $\leq 31 \mathrm{e} . \mathrm{u}$. The heat of sublimation is $60 \pm 2 \mathrm{kcal} / \mathrm{mole}$ from 1026 to $1349 \mathrm{~K}$. as follows:

Glassner's data, (113) some of which are based on estimates, are
Melting Point: $\quad 1430 \mathrm{~K}$
Boiling Point: $2150 \mathrm{~K}$
Heat of Fusion: $89 \mathrm{kcal} / \mathrm{mole}$
Entropy of Fusion: 6.2 e.u.
Heat of Vaporization: $55 \mathrm{kcal} / \mathrm{mole}(2150 \mathrm{~K})$
Entropy of Vaporization: 26 e.u. (2150 K)
Entropy of $\mathrm{NiF}_{2}(\mathrm{c})$ at $298 \mathrm{~K}: 17.59 \mathrm{e} . \mathrm{u}$.

For $\mathrm{NiF}_{2}(\mathrm{c})$ :

$$
\begin{aligned}
\mathrm{H}_{\mathrm{T}}-\mathrm{H}_{298} & =-4.214+13.0 \mathrm{~T}+3.8 \times 10^{-3} \mathrm{~T}^{2} \\
\mathrm{C}_{\mathrm{p}} & =13.0+7.6 \times 10^{-3} \mathrm{~T} \\
\mathrm{~S}_{\mathrm{T}} & =-58.7+7.6 \times 10^{-3} \mathrm{~T}+29.94 \log \mathrm{T} \\
\frac{\mathrm{F}_{\mathrm{T}}-\mathrm{H}_{298}}{\mathrm{~T}} & =71.7-3.8 \times 10^{-3} \mathrm{~T}=29.94 \log \mathrm{T}=\frac{4.214}{\mathrm{~T}}
\end{aligned}
$$


For $\mathrm{NiF}_{2}(\ell)$ :

$$
\begin{aligned}
\mathrm{H}_{\mathrm{T}}-\mathrm{H}_{298} & =-2.492+24 \mathrm{~T} \\
\mathrm{C}_{\mathrm{p}} & =24 \\
\mathrm{~S}_{\mathrm{T}} & =-121.6+55.27 \log \mathrm{T} \\
\frac{\mathrm{FT}_{\mathrm{T}}-\mathrm{H}_{298}}{\mathrm{~T}} & =145.6-55.27 \log \mathrm{T}-\frac{2.492}{\mathrm{~T}}
\end{aligned}
$$

For $\mathrm{NiF}_{2}(\mathrm{~g})$ :

$$
\begin{aligned}
\mathrm{H}_{\mathrm{T}}-\mathrm{H}_{298} & =71.86+15 \mathrm{~T} \\
\mathrm{C}_{\mathrm{p}} & =15 \\
\mathrm{~S}_{\mathrm{T}} & =-27.0+34.55 \log \mathrm{T} \\
\frac{\mathrm{FT}_{\mathrm{T}}-\mathrm{H}_{298}}{\mathrm{~T}} & =42-34.55 \log \mathrm{T}+\frac{71.86}{\mathrm{~T}}
\end{aligned}
$$

The heats and free energies of formation are listed as follows:

$$
\begin{aligned}
& \mathrm{Ni}(\mathrm{c}, \alpha)+\mathrm{F}_{2}(\mathrm{~g})=\mathrm{NiF}_{2}(\mathrm{c}) \quad[298-626 \mathrm{~K}] \\
& \Delta \mathrm{H}_{\mathrm{f}_{298}}=-158 \mathrm{kcal} / \mathrm{mole} \\
& \Delta F_{\text {f298 }}=-147 \mathrm{kcal} / \mathrm{mole} \\
& \Delta \mathrm{H}-\Delta \mathrm{H}_{\mathrm{f}, 298}=0.069+0.6 \mathrm{~T}+0.05 \times 10^{-3} \mathrm{~T}^{2}-\frac{0.8 \times 10^{5}}{\mathrm{~T}} \\
& \Delta \mathrm{C}_{\mathrm{p}}=0.6+0.1 \times 10^{-3} \mathrm{~T}+\frac{0.8 \times 10^{5}}{\mathrm{~T}^{2}} \\
& \Delta S=-41.4+0.1 \times 10^{-3} \mathrm{~T}+1.382 \log \mathrm{T}-\frac{0.4 \times 10^{5}}{\mathrm{~T}^{2}} \\
& \Delta F-\Delta H_{1298}=0.069+42.0 \mathrm{~T}-0.05 \times 10^{-3} \mathrm{~T}^{2}-1.382 \mathrm{~T} \log \mathrm{T}-\frac{0.4 \times 10^{5}}{\mathrm{~T}} \\
& \mathrm{Ni}(\mathrm{c}, \beta)+\mathrm{F}_{2}(\mathrm{~g})=\mathrm{NiF}_{2}(\mathrm{c}) \quad[626-1430 \mathrm{~K}] \\
& \Delta \mathrm{H}-\Delta \mathrm{H}_{\mathrm{f}, 298}=0.165-1.3 \mathrm{~T}+2.7 \times 10^{-3} \mathrm{~T}^{2}-\frac{0.8 \times 10^{5}}{\mathrm{~T}} \\
& \Delta C_{p}=-1.3+5.4 \times 10^{-3} T+\frac{0.8 \times 10^{5}}{T^{2}} \\
& \Delta S=-32.3+5.4 \times 10^{-3} \mathrm{~T}-2.994 \log \mathrm{T}-\frac{0.4 \times 10^{5}}{\mathrm{~T}^{2}}
\end{aligned}
$$




$$
\mathrm{Ni}(\mathrm{c}, \beta)+\mathrm{F}_{2}(\mathrm{~g})=\mathrm{NiF}_{2}(\ell) \quad[1430-1728 \mathrm{~K}]
$$

$\Delta H-\Delta H_{f, 298}=1.887+9.7 \mathrm{~T}-1.1 \times 10^{-3} \mathrm{~T}^{2}-\frac{0.8 \times 10^{5}}{\mathrm{~T}}$

$$
\Delta \mathrm{C}_{\mathrm{p}}=9.7-2.2 \times 10^{-3} \mathrm{~T}+\frac{0.8 \times 10^{5}}{\mathrm{~T}^{2}}
$$

$$
\Delta S=-95.2-2.2 \times 10^{-3} T+22.34 \log T-\frac{0.4 \times 10^{5}}{T^{2}}
$$

$\Delta \mathrm{F}-\Delta \mathrm{H}_{\mathrm{f}, 298}=1.887+104.9 \mathrm{~T}+1.1 \times 10^{-3} \mathrm{~T}^{2}-2234 \mathrm{~T} \log \mathrm{T}-\frac{0.4 \times 10^{5}}{\mathrm{~T}}$

$$
\mathrm{Ni}(\ell)+\mathrm{F}_{2}(\mathrm{~g})=\mathrm{NiF}_{2}(\ell) \quad[1728-2150 \mathrm{~K}]
$$

$\Delta \mathrm{H}-\Delta \mathrm{H}_{\mathrm{f}, 298}=1.519+6.5 \mathrm{~T}-0.2 \times 10^{-3} \mathrm{~T}^{2}-\frac{0.8 \times 10^{5}}{\mathrm{~T}}$

$$
\begin{aligned}
\Delta C_{p} & =6.5-0.4 \times 10^{-3} T^{2}+\frac{0.8 \times 10^{5}}{T^{2}} \\
\Delta S & =-76.9-0.4 \times 10^{-3} \mathrm{~T}+14.97 \log \mathrm{T}-\frac{04 \times 10^{5}}{\mathrm{~T}^{2}}
\end{aligned}
$$

$\Delta \mathrm{F}-\Delta \mathrm{H}_{\mathrm{f}, 298}=1519+83.4 \mathrm{~T}+0.2 \times 10^{-3} \mathrm{~T}^{2}-14.97 \mathrm{~T} \log \mathrm{T}-\frac{0.4 \times 10^{5}}{\mathrm{~T}}$

$$
\mathrm{Ni}(l)+\mathrm{F}_{2}(\mathrm{~g})=\mathrm{NiF_{2 }}(\mathrm{g}) \quad[2150-2500 \mathrm{~K}]
$$

$\Delta H-\Delta H_{f, 298}=74.87-25 \mathrm{~T}-0.2 \times 10^{-3} \mathrm{~T}^{2}-\frac{0.8 \times 10^{5}}{\mathrm{~T}}$

$$
\begin{aligned}
\Delta C_{p} & =-2.5-0.4 \times 10^{-3} \mathrm{~T}+\frac{0.8 \times 10^{5}}{\mathrm{~T}^{2}} \\
\Delta S & =17.7-0.4 \times 10^{-3} \mathrm{~T}-5758 \log \mathrm{T}-\frac{0.4 \times 10^{5}}{\mathrm{~T}^{2}}
\end{aligned}
$$

$\Delta F-\Delta \mathrm{H}_{\mathrm{f}, 298}=74.87-20.2 \mathrm{~T}+0.2 \times 10^{-3} \mathrm{~T}^{2}+5.758 \mathrm{~T} \log \mathrm{T}-\frac{04 \times 10^{5}}{\mathrm{~T}}$ 


\section{BIBLIOGRAPHY}

1. Berzelius, J. J., Schweigger's Journ. 32, 156 (1821)。

2. Berzelius, J. J., Pogg. Ann。 1, 26 (1824).

3. de Marignac, J. C. G., Ann. Mines 15, 262 (1859).

4. Delafontaine, M., Arch. Sciences Geneva 30, 232 (1860).

5. de Marignac, J.C.G。, Ann. Chim, Phys.60, 257 (1860).

6. de Marignac, J. C. G., Compt, rend. 50, 952 (1860).

7. Weber, R., Schweigger's Journ. 120, 292 (1863)。

8. Streng, A., Liebig's Ann. 129, 225 (1864)。

9. Gore, G. Proc.Roy. Soc. 20, 441 (1872).

10. Gore, $G_{n}$, ibid. 21, 140 (1873).

11. Clarke, F。W. Am. J. Science 13, 291 (1844).

12. Schulze, H., J.prakt. Chem. 21, 407 (1880).

13. Christensen, O. T., ibid, 34, 41 (1886)

14. Wagner, R。, Ber, 19,896 (1886).

15. Peterson, E。, Z, phys. Chem.4, 384 (1889),

16. Peterson, E, Joprakt. Chem。40,61 (1889).

17. Piccini, A. and Georgis, G. Attı Accad. Lincei, 6, 130 (1890).

18. Poulenc, M.C., J. Pharm. Chim.26, 200 (1892).

19. Poulenc, M.C., Compt。rend.114, 746 (1892).

20. Poulenc, M. C. ibid. 114, 1426 (1892).

21. Piccini, A. and Georgis, G., Gazz. Chim. Ital.22, 55 (1892).

22. Poulenc, M. C., "Contribution à étude des fluorures anhydres et cristallises," Paris (1893). 
23. von Helmholt, H., Z. anorg. Chem. 3, 133 (1893).

24. Poulenc, M.C., Ann. Chim. Phys.2, 41 (1894).

25. Weinland, R. F. and Köppen, O., Z. anorg. Chem. 22, 271 (1900).

26. Böhm, E., ibid. 43, 330 (1905).

27. Barbieri, G. A. and Calzolari, J., Atti Accad. Lincei 14, 464 (1905).

28. Gossner, B., Z. anorg. Chem. 43, 331 (1905).

29. Gore, G., Electrochem., London 86 (1906).

30. Bohm. E., "Zur Kenntnis Fluoride," Giessen (1906).

31. Gossner, B., Z. Krist. 42,488 (1906).

32. Rimbach, E., and Kilian, H.F.C., Liebig's Ann. 368, 101 (1909)

33. Costachescu, N。, Ann. Science Univ. Jassey 7, 5 (1911).

34. Edmister, F. H. and Cooper, H. C., Science 50, 444 (1919).

35. Edmister, F. H. and Cooper, H. C., J. Am. Chem. Soc. 42, 2419 (1920).

36. Edmister, F. H. and Cooper, H. C., Chem. News 122, 27 (1951).

37. Clark, G. L., Am. J. Sci. 7, 1 (1925).

38. von Wartenberg, $H$, and Fitzner, O., Z. anorg. Chem. 151, 313 (1926).

39. von Wartenberg, H., ibid. 326 (1926).

40. Deniges, G., Compt. rend. 183, 55 (1926).

41. Deniges, G., Bull, Soc.Pharm. Bordeaux 69, 216 (1926).

42. Goldschmidt, V. M. et al, Schrift. Akad. Oslo 1 (1926).

43. Ferrari, A., Atti Accad. Lincei 3, 324 (1926).

44. Biltz, W。and Rahlfs, E., 2. anorg. Chem. 166, 374 (1927).

45. Jellinek, K. and Rudat, A., ibid. 175, 281 (1928). 
46. Rudat, A., "Uber die Fluortension von Metallfluoriden und die chemischen Konstanten von Fluor und Fluorwasserstoff, "Danzig (1928).

47. Carter, R. H. Ind. Eng. Chem. 20, 1195 (1928).

48. Beck, G。, Z anorg. Chem. 182, 332 (1929).

49. Ascher, E., "Die Fluoride der VIII Gruppe des periodischen Systems," Breslau (1929).

50. Ruff, O. and Ascher, E., Z. anorg Chem. 183, 193 (1929).

51. Wilke-Dörfurt, E. and Mureck, H, G., 1bid. 184, 121 (1929).

52. Ray, P.C. and Sarkax, P.B., J. Indran Chem. Soc. 6, 987 (1929).

53. "International Critical Tables," Vol.VI, p. 358, 364, McGraw-Hill, New York (1929).

54. Ferrari, A, Atti Congress Naz, Chim Pura Appl。3, 452 (1930).

55. Cabrera, B. and Duperier, A., Anal. F1s.Quim. 29, 5 (1931).

56. Ray, N. N., Z. anorg. Chem, 205, 257 (1932).

57. Fereday, R.A., Proc. Phys. Soc.44, 274 (1932)

58. Terrain, Atti III Congress Naz, Chum, Pura Appl, 5, 452 (1932).

59. Serres, A, Ann. Physique 20, 441 (1933).

60. Kurtenacker, A., Finger, W, and Hey, F, Z, anorg. Chem 211, 281 (1933).

61. Kurtenacker, A, Finger, $W_{,}$, and Hey, F, ibid. 211, 83 (1933).

62. Tammann, G. and von Samson-Himmelsjerna, H. O, ibid, 216, 288 (1934)

63. Henkel, P. and Klemm, W., ibid. 222, 70 (1935).

64. Henkel, P. and Klemm, W. ibid 222, 73 (1935).

65. Domange, L., Compt. rend. 202, 1276 (1936). 
66. Jahn-Held, and Jellinek, K. Z. Elektrochem. 42, 401 (1936).

67. Domange! L., Ann. Chem. Justus Liebigs 7,225 (1937),

68. de Haas, W. J. and Schultz, B.H., Physica 6, 481 (1939).

69. de Haas, W. J., Schultz, B. H. and Koolhaas, J., ibid. 7, 57 (1940).

70. Whitney, J., Smith, $F_{0}$, and Miller, A. J., "Preparation and Stability of Cobalt Trifluoride," AECD-3917, Oct.15, 1945.

71. Bizette, H. Ann. Phys. 1, 233 (1946).

72. Delwaulle, M. L. and Francois, F. Compt. rend. 222, 550 (1946).

73. Bizette, Ho, Chem。Zentr。I, 494 (1947).

74. Klemm, W. and Huss, E。 Z,anorg。Chem, 258, 221 (1949).

75. Sidgwick, N. V., "The Chemical Elements and their Compounds," p. 1432, Clarendon Press, Oxford (1950)

76. Simons, J. H., "Fluorine Chemistry," Vol. I, p. 68, Academic Press, New York (1950).

77. Whitaker, G.C., Corrosion, 6, 283 (1950).

78. Priest, H. F., "Inorganic Synthesis, Vol. III, Anhydrous Metal Fluorides,"p.171, L。 F, Audrieth, ed, McGraw-Hill, New York (1950).

79. Brewer, L." "Chemistry and Metallurgy of Miscellaneous Materials," L. L. Quill, ed, McGraw-Hill, New York (1950).

80. Erickson, R.A., "Quarterly Progress Report for the Period Ending March 20, 1951, Physics Division, S.Bernstein, ed, ORNL-1005, July 24, 1951 。

81. Lancaster, F.W. and Gordy, W. J.Chem. Phys.19, 1181 (1951).

82. Hood, G. C. and Hoyski, M.M., J.Am. Chem.Soc., 73, 2738 (1951).

83. Kirk, R. E. and Othmer, D. F , "Encyclopedua of Chemical Technology," Vol. VI, p.710, Interscience, New York (1951).

84. Kellogg, H。H. J. of Metals, Transactions, AIME 191, 137 (1951). 
85. Slesser and Schram, "Fluorine Technology," NNES VII-1, McGraw-Hill, New York (1951).

86. Wagnex, G. and Balz, D。, Z. Elektrochem. 56, 574 (1952),

87. Rochow, E. G. and Kukin, I., J.Am. Chem. Soc. 74, 1615 (1952).

88. Haendler, H. M., Patterson, W. L., Jro and Bernard, W. J., "The Reaction of Fluorine with Zinc, Nickel, and Some of their Binary Compounds; Some Properties of Zinc and Nickel Fluorides," NYO-3160, February 1, 1952.

89. Haendler, H, M., Patterson, W, L。, Jr. and Bernard, W。 J., I. Am. Chem. Soc. 74, 3167 (1952)。

90. Wollan, E. O., et al, "Neutron Diffraction, Section I of Quarterly Progress Report for Period Ending June 20, 1951, Physics Division," ORNL-1092, January 16, 1952.

91. Landau, $R_{\text {。 }}$ Corrosion 8, 283 (1952).

92. Perkins, M.A. and Couper, M., U.S. Patent 2,588,041, March 4, 1952.

93. Rossini, F。R., et al, "Selected Values of Chemical Thermodynamic Properties, "National Bureau of Standards Circular 500 (February 1, 1952).

94. Weltner, W, and McMillan, W. G, "The Chemistry of the Diffusion Process," NNES II-6, Ch。12 (1952)

95. Jache, A.W. and Cady, G. H., J. Phys. Chem. 56, 1106 (1952).

96. Balz, D., Naturwiss. 40, 241 (1953).

97. LaLande, W.A., Jr。 and Mockrin, I, U.S. Patent 2,659,657, U. S. Patent 2,659,658, (November 7, 1953).

98. Stout, J. W. and Catalano, E., Phys, Rev. 92, 1575 (1953).

99. Erickson, R. A. ibid. 90, 779 (1953).

100. Sheft, I., Hyman, H. H., and Katz, J. J., J.Am. Chem, Soc. 15,5221 (1953).

101. Matarrese, L. M and Stout, J.W., ibid, 94, 1792 (1954) 
102. Aynsley, E. E. Hetherington, $G$ and Robinson, P. L., J.Chem. Soc. 1119 (1954).

103. Stout, J.W. and Reed, S.A., J.Am. Chem.Soc. 76, 5279 (1954).

104. "Catalano, E。 and Stout, J。W., J.Chem. Phys, 23, 1284 (1955).

105. Farrar, R. L。, Jr。and Smith, H.A., J.Phys.Chem。59, 763 (1955).

106. Farrar, R. L., Jr。 and Smith, H。A, J。Am. Chem. Soc, 77, 4502 (1955).

107. Stout, J.W. and Catalano, E。, J.Chem. Phys, 23, 2013 (1955).

108. Elliott, No, "The Magnetic Susceptibilities of $\mathrm{NiF}_{2}$ and $\mathrm{CoF}_{2}$ at Intermediate Temperatures," BNL-225.

109. Insley, $H_{\circ}$, et al, "Optical Properties and X-ray Diffraction Data for Some Inorganic Fluoride and Chloride Compounds, "ORNL-2192, Nov. 8, 1956.

110. Moriya, T。, et al, J. Phys.Soc, Japan 11, 211 (1956).

111. Van Atta, F.A., "Inorganic Fluorides, "National Safety Council Data Sheet D-442 (1957).

112. Steindler, M. Jo and Vogel, R. C. " Coxrosion of Materials in the Presence of Fluorine at Elevated Temperatures, ${ }^{\text {n }}$ ANL 5562 , January, 1957.

113. Glassner, A., The Thermochemical Properties of the Oxides, Fluorides, and Chlorides to $2500 \mathrm{~K}$, $\mathrm{ANL}-5750$ (January, 1958)。

114. Farber, M。, Meyer, R。T.and Margrave, J.L., J. Phys Chem.62, 883 (1958). 